\title{
Free associations and dominance ratings of homophones for young and older adults
}

\author{
KATHERINE K. WHITE and LISE ABRAMS \\ University of Florida, Gainesville, Florida
}

\begin{abstract}
Homophones are words that share phonology but differ in meaning and spelling (e.g., beach, beech). This article presents the results of normative surveys that asked young and older adults to free associate to and rate the dominance of 197 homophones. Although norms exist for young adults on word familiarity and frequency for homophones, these results supplement the literature by (1) reporting the four most frequent responses to visually presented homophones for both young and older adults, and (2) reporting young and older adults' ratings of homophone dominance. Results indicated that young and older adults gave the same first response to $67 \%$ of the homophones and rated homophone dominance similarly on $60 \%$ of the homophone sets. These results identify a subset of homophones that are preferable for research with young and older adults because of age-related equivalence in free association and dominance ratings. These norms can be downloaded from the Psychonomic Society's Web archive, www.psychonomic.org/archive/.
\end{abstract}

Ambiguous words have been used in cognitive research to investigate the relative influence of phonology, orthography, and semantics during word recognition and retrieval, with or without context (e.g., Gottlob, Goldinger, Stone, \& Van Orden, 1999; Lesch \& Pollatsek, 1993; Lukatela \& Turvey, 1994; Simpson, 1984; Van Orden, 1987; Vu, Kellas, \& Paul, 1998; White \& Abrams, 2004). Ambiguous words in these studies include homophones, homographs, and homonyms, or words that share some combination of phonology and/or orthography but have different meanings associated with them. Although the definitions that are associated with the three different types of ambiguous words are often used interchangeably, this article uses Webster's definitions (Mish, 1991): Homophones (e.g., beach, beech) are two words that share the same sound (phonology), but differ in spelling (orthography) and meaning (semantics). Homographs (e.g., dove as in "a bird" or "past tense of dive") differ in phonology and semantics, but share orthography. Homonyms share both phonology and orthography, but have multiple meanings (e.g., ball as in "a round object often used in sports" or "a fancy dance affair"). A variety of normative studies have provided association norms for homonyms in order to determine which associative meaning is more dominant (e.g., Gorfein, Viviani, \& Leddo, 1982; Nelson,

A National Research Service Award from the National Institute of Mental Health, awarded to K.K.W. as a predoctoral fellowship, supported portions of this research. We thank Kristen Gregersen and Leila Tolaymat for assistance in data collection, as well as Judith Kroll and two anonymous reviewers for comments on an earlier version of this article. Correspondence should be addressed to K. White, Department of Psychology, College of Charleston, 66 George Street, Charleston, SC 29424 (e-mail: whitek@cofc.edu) or L. Abrams, Department of Psychology, University of Florida, Gainesville, FL 32611-2250 (e-mail: abrams@ufl.edu).
McEvoy, Walling, \& Wheeler, 1980; Twilley, Dixon, Taylor, \& Clark, 1994). These studies ask participants to provide the first word that comes to mind (i.e., to free associate) when they hear or see a word. Participants' responses are then categorized into the most common meanings given (e.g., the primary [i.e., dominant] and secondary [i.e., subordinate] meanings for ball are bat and dance, respectively [Twilley et al., 1994]). Thus, researchers have a variety of norms to access when using homonyms as stimuli.

In contrast to homonyms, few normative studies exist for either homographs or homophones, and therefore the present studies fill a gap in the literature by presenting homophone norms. With homonyms, free associations provide information both on the strongest associations to a homonym and on which meaning of the homonym is dominant (via the first association to the homonym; e.g., responding "soccer" for ball indicates that the "round object" meaning of ball is dominant). With homophones, however, free associations and dominance ratings must be assessed separately, which no previous study has done. That is, unlike homonyms, which are represented by one word (e.g., ball), homophones include two or more words (e.g., beach, beech), both of which must be free associated to separately.

Existing normative studies of homophones differ in their purposes and from the studies presented here. Kreuz (1987) asked college students to subjectively rate 828 homophones for their familiarity (from very common to very uncommon), and later experimentally compared the familiarity ratings to Kučera and Francis's (1967) frequencies. Kreuz found that although familiarity and frequency ratings were highly correlated, familiarity ratings were better predictors of word recognition latencies. In contrast to obtaining familiarity ratings for each homophone, 
the present study asked participants to choose the more dominant member of a homophone set. Olson and Kausler (1971) obtained college students' ratings of the orthographic distinctiveness of 139 homophones (i.e., the uniqueness of the orthography between two homophones within a set; e.g., you and ewe vs. seam and seem), and those ratings therefore differ substantially from the dominance and free association norms presented here. Only one published study has asked participants to free associate to homophones: Galbraith and Taschman (1969) presented homophones orally and asked college students to spell the homophone they heard and then to free associate to it. However, their article did not provide the associations, possibly because the authors were more interested in which word within each homophone set would be spelled and associated to (a measure of dominance), and also because free associations were obtained from only one homophone within a set. Furthermore, Galbraith and Taschman elicited dominance via auditory presentation of homophones, whereas our study used visual presentation. In an attempt to gather a more complete set of norms for homophones, this article presents both free association and dominance norms for 96 homophone sets (197 total words) from a large sample of both young and older adults.

Our decision to include both young and older adults in these studies was straightforward: There are no published homophone free association or dominance norms for older adults. Rather, researchers using ambiguous words as a measure to compare processes and performance between young and older adults have referred to norms based on young adults' estimates (e.g., Davis et al., 1990; Rose, Yesavage, Hill, \& Bower, 1986). For example, Davis et al. (1990) and Rose et al. (1986) examined priming via homophone spelling tests in young and older adults, but they used dominance estimates for the homophones from a pool of younger adults (Galbraith \& Taschman, 1969). These studies assume that two cohorts separated by at least 40 years have identical dominance estimates for different meanings of ambiguous words, which is not necessarily true. For example, genes might be the more dominant representation of the phonology /dzinz/ for older adults who are more likely to be dealing with health and disease issues in later life; young adults might think of jeans because jeans are an article of clothing often worn by younger people. As suggested elsewhere (Bowles \& Poon, 1982), investigations of potential age differences in semantic processes should equate age groups on verbal skills. Although it may not always be possible to equate young and older adults on dominance, researchers can control for it by using normative estimates.

Word frequency estimates by young adults exist for homophones (e.g., Kučera \& Francis, 1967) and are a critical issue in research on language and memory because a word's frequency can influence factors such as speed of access to its representation (e.g., a high-frequency word is accessed faster than a low-frequency word; Forster \& Chambers, 1973). The most popular reference for word frequency estimates is Kučera and Francis (1967), who calculated a word's frequency by how often it appeared in print per one million words (but see also Baayen, Piepenbrock, \& van Rijn, 1993; Brown, 1984; Carroll, Davies, \& Richman, 1971; Dahl, 1979; Lund \& Burgess, 1996; MetaMetrics, Inc., 2003; Thorndike \& Lorge, 1944; Zeno, Ivens, Millard, \& Duvvuri, 1995). We argue that dominance is an additional variable relevant to homophones because dominance may play a role in how quickly a homophone is accessed. Although a homophone's dominance is often closely related to its frequency, sometimes two homophones can have similar frequencies while one homophone is thought of as the dominant one (e.g., ail and ale have similar Kučera \& Francis [1967] frequencies of 0 and 1 words per million, but ale is considered dominant). Furthermore, Kreuz's (1987) finding that familiarity was a better measure of word recognition than was word frequency demonstrates that multiple word characteristics are important to consider or to control for when one is conducting language research.

In summary, previous normative studies of ambiguous words have focused mainly on homonyms, and the studies that used homophones either did not assess or did not report the homophones' strongest associations. Furthermore, none of the studies included norms for older adults. The studies conducted here supplement prior normative studies by presenting the most frequently reported associations for 197 homophones and by including an assessment of homophone dominance, which can be used in comparison with frequency estimates. In addition, we included both young and older adults, to provide researchers with normative stimuli that can be used for cognitive aging studies. Study 1 presents the results of a free association survey in which a total of 440 young and older adults were asked to read ambiguous words and to respond to each word with the first word that came to mind (e.g., what is the first word that comes to mind when you read the word beach?). Study 2 presents the results of a corresponding dominance survey in which the same 440 participants were asked to circle the individual word within each homophone set that they considered to be dominant. Because a larger sample of participants could be obtained through a mailing of the written survey, a written (visual) dominance survey was used (in contrast to auditory [oral] presentation of homophones; see the Method section of Study 2).

\section{STUDY 1 \\ Free Associations}

\section{Method}

Participants. Two hundred twenty young adults from 17 to 25 years old $(M=19.72$ years, $S D=2.30 ; 150$ females, 70 males, with 1 participant not reporting her age) and 220 older adults between the ages of 62 and $91(M=73.49, S D=6.86 ; 111$ females, 106 males, 3 unknown, with 5 participants not reporting ages) completed the surveys. The young adults were recruited from introductory and cognitive psychology courses at the University of Florida and participated for extra credit or partial fulfillment of course 
credit. The older adults were taken from the Cognition and Aging Lab Participant Pool, which consists of older adults in the Gainesville community recruited from the University of Florida Alumni Association, local organizations, and churches. The majority of the young and older adults reported English as their native language: Out of the 219 young adults who reported a native language, $92 \%$ reported English as that language, with 4\% reporting Spanish, and $4 \%$ reporting some other language. Out of the 199 older adults who reported a native language, $98 \%$ reported English, $<1 \%$ ( 1 person) reported Spanish, and $<2 \%$ ( 3 people) reported some other language. The young adults had fewer years of education (range $=$ 11-17 years, $M=13.95, S D=1.27$ ) than did the older adults $($ range $=12-26$ years, $M=17.23, S D=2.59)[t(396)=15.70, p<$ $.001]$.

Materials. The free association survey included a list of 96 sets of homophones, with 91 homophone pairs and 5 homophone triplets, totaling 197 homophones (one homophone, cite, in the site/sight/cite triplet was inadvertently left off the survey, thus making sight/site count as a pair instead of a triplet). Homophones were chosen from previous normative studies of homophones (Galbraith \& Taschman, 1969; Kreuz, 1987; Olson \& Kausler, 1971). ${ }^{1}$ The words were randomly assigned a position (1-197) on the list, with the stipulation that the homophones within a set (e.g., beach/beech) were separated by at least 10 other words. Two survey forms were constructed in such a way that half of the forms listed one member of a homophone set first and the other half listed the other member of the homophone set first (for sets with three homophones, two different orderings of the three words were made).

Procedure. Adults completed the free association survey prior to the dominance survey. The survey was preceded by a set of instructions informing participants that they would see a list of words and that each word would have a blank next to it. The participants were asked to read and to respond to each word with the first word that came to mind. The participants were also instructed to write "no response" if a response did not immediately and automatically come to mind. On average, a homophone was responded to by 214 older adults and 203 young adults. Two examples not included in the test list were provided in the instructions.

\section{Results and Discussion}

The results of the free association survey are presented in Tables A1 (young adults) and A2 (older adults). These tables list each homophone in bold font with the total number of participants who responded to that homophone in parentheses. In the columns that follow each homophone, the top four free associates - that is, responsesfor that homophone are listed and are followed in parentheses by the percentage of time that response was given (note that only two responses are presented in this article [the full list, including all four responses, can be found in the Archived Materials] and that if there was a tie for fourth response, all responses with that percent are listed in the table). The homophones in Tables A1 and $\mathrm{A} 2$ are listed in alphabetical order by the homophone within a set that comes first in the alphabet (e.g., you is listed under "e" because it is paired with ewe).

Association response percentages were calculated by taking the number of similar responses given for a homophone and dividing it by the total number of responses for that homophone (e.g., out of the 154 young adults who responded to ail, sick was given by 44 of them). The percentages exclude "no response" responses (e.g., 154 out of 220 young adults gave a response to ail, and therefore their percentages are calculated using 154 as the de- nominator). At least $2 \%$ of the participants had to give a response in order for that response to be included in Tables A1 and A2.

Responses in Tables A1 and A2 are grouped together if they share strong morphological overlap, including singular and plural forms of a word (e.g., hill[s], ox[en], mice/mouse) and present and past tenses (e.g., owe $[d]$, catch/caught). In addition, words that are semantically similar and share morphemes were grouped together (e.g., sing/song, row[ing], part[ial ]s). Because these norms will likely be used for research in which semantic associations are the measure of interest, four types of responses considered not to be useful for such research were eliminated from the tables: (1) responses that were semantically associated with another homophone in the set (e.g., beer for ail) totaled $8 \%$ of young adults' and $2 \%$ of older adults' responses; (2) homophone responses (e.g., ail for ale) totaled $5 \%$ and $4 \%$ of young and older adults' responses, respectively; (3) regionally unique responses (e.g., oaks for mall, which refers to the Oaks Mall in Gainesville, Florida) were given by less than 1\% of young adults and no older adults; and (4) responses that contained the homophone altered by a simple morphological prefix (e.g., [a]lone) or suffix (e.g., build [ing]) were given for less than $1 \%$ of young and older adults' responses. Even though these four types of responses are not listed in the tables, they are still included in the calculation of the total number of responses given for a homophone, as were responses that did not correspond to one of the top four associates.

Descriptive results from Tables A1 and A2 indicated that young and older adults gave the same first response for $66.5 \%$ of the homophones, indicating moderate consistency across age groups at least for the strongest associations to homophones. Even when young and older adults did not give the same first response, their top four responses contained at least one shared response between the age groups for $32.5 \%$ of the homophones. Indeed, only two homophones (beech, hale) did not have any overlapping responses between the age groups. Demonstrating this similarity in responses between age groups separated by at least 40 years illustrates the relative stability of norms over time. Furthermore, across all first responses, young $($ median $=29 ; M=33.05, S D=17.23$ ) and older (median $=31 ; M=36.79, S D=18.78)$ adults had similar median and mean association strengths for their first responses. Finally, Figure 1 illustrates the frequency distribution of the number of first association responses by young and older adults. The figure is skewed positively for both young and older adults, suggesting that there was a good deal of variability in first responses within both age groups. For young adults, over half of the homophones had first responses that were only given by $11 \%-30 \%$ of participants. A similar picture emerged for older adults, although their mode was slightly shifted to the right.

Despite the similarity in responses for a large number of the homophones, young and older adults differed in their first responses for one third of the 197 homophones. 


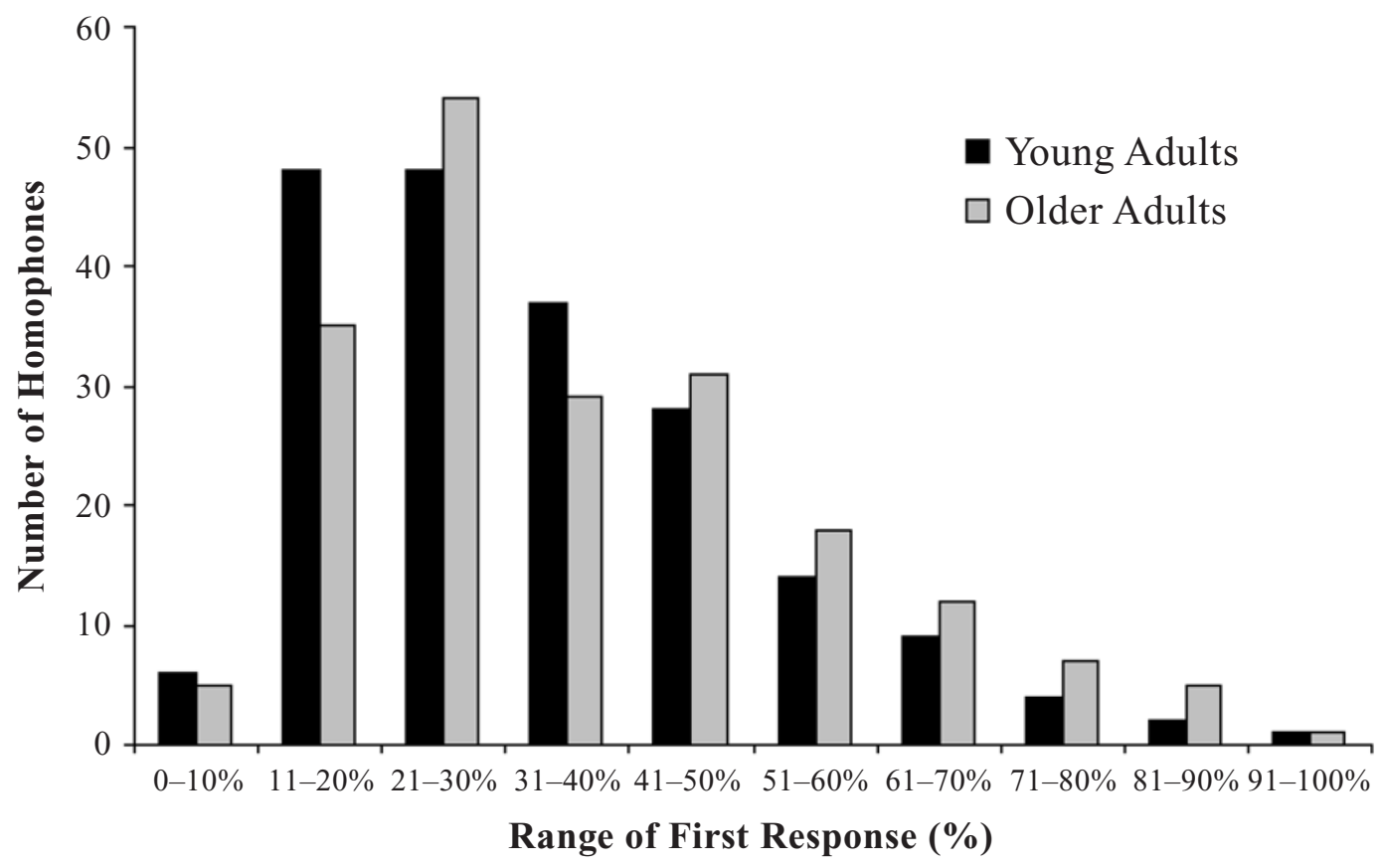

Figure 1. Frequency distribution for the percentage of time a response was given as the first free association for young and older adults.

One possible explanation for this age-related variability is provided by cohort differences. Certain associations are more available to one age group because of their life experiences; for example, young adults' most frequent associate to idol is Billy, in reference to the 1980s rock singer, but that associate is never produced by older adults. Another explanation is provided by vocabulary differences between the age groups. Older adults consistently perform better on vocabulary tests than young adults (e.g., Kemper \& Sumner, 2001; Verhaeghen, 2003), suggesting that older adults are more likely to produce unique associations or associations that are unknown to young adults (see also Burke \& Peters, 1986). For example, young adults never gave an appropriate associate to hale, most likely because they did not know what the word meant. Although we did not measure vocabulary level in our sample, the older participants in this study have a higher level of education and are likely to have larger vocabularies.

\section{STUDY 2 \\ Dominance}

\section{Method}

Participants. The same 220 young adults and 220 older adults who completed the free association survey also completed the dominance survey.

Materials. The dominance survey included the same 96 sets (pairs and triplets) of homophones as in the free association survey: 90 sets consisted of two homophone words (e.g., beach, beech) and 6 sets included three homophone words (e.g., write, right, rite) (note that in the written dominance survey, cite was included in the homophone set site/sight/cite, making this set a triplet). Homo- phones within a set were typed on the same line, and sets were randomly assigned a position (1-96) on the list. In order to avoid ordering effects of homophones within a set, two lists were made, such that one member of each homophone set came first half of the time and the other member came first the other half of the time (for sets with three homophones, two different orderings of the three words were made). The word equal was typed next to each homophone set to give participants the option of choosing equal if they thought that homophones in a set were equal in dominance (i.e., there was no obvious choice for dominant and subordinate).

Procedure. The participants completed the dominance survey after finishing the free association survey. A separate set of instructions defined homophone and gave the participants an example of a homophone pair that was not included in the survey (sale, sail). The participants were told that they would see a list of homophone pairs and triplets and that they were to choose the individual word that they felt to be more dominant in the English language. The following definition was given for dominance: "The dominant word in each pair corresponds to the meaning you think of first upon hearing the word; you might think about the sound of the word and which spelling/meaning comes to mind first. It might be a word that you encounter often in reading, talking, watching television, or listening to the radio." The word equal was included in each homophone set, and the participants were instructed to circle equal in cases in which they considered both (or all three) words to be equally dominant. One example was included to orient participants to the task prior to beginning the survey.

\section{Results and Discussion}

Results of the dominance survey are presented in Tables A3 and A4. The first column of these tables lists each homophone (note that unlike in the free association Tables A1 and A2, we do not list the number of participants who responded to each homophone set because rarely did a homophone set get skipped, and therefore 
the response rate was near $100 \%$ ). The next column includes Kučera and Francis's (1967) written frequency rating (KF-FREQ) for that homophone. Words that did not have an assigned frequency in Kučera and Francis were given a zero (0) frequency. The third and fourth columns contain the percent of time that young and older adults chose a homophone as dominant, respectively. Homophone sets are listed alphabetically by the homophone within each set that comes first in the alphabet (as in alphabetical listings in the free association tables). Note that the percentages may not add up to $100 \%$, because participants were allowed to rate homophones within a set as equal in dominance. In order to determine the percentage of equal dominance in any individual homophone set, the dominance percentages within a set can be summed and subtracted from $100 \%$ (e.g., $21 \%$ is the remainder after subtracting $59.5 \%$ for aisle and $19.5 \%$ for isle from 100\%). On average, young and older adults rated $16.73 \%$ and $18.63 \%$ of the homophones within a set as equal in dominance, respectively.

Tables A 3 and A4 report the mean percentage of time a homophone was chosen as dominant, for young and older adults. However, the dominance results are grouped into two tables for ease of interpretation. Table A3 includes homophones within a set (e.g., ail, ale) that were consistently rated as dominant or subordinate by both young and older adults. We defined a homophone as dominant if it was rated as dominant by at least $50 \%$ of the participants in both age groups. Table A3 uses bold font to indicate the dominant homophone in each set. Fifty-eight of the 96 homophone sets are included in Table A3, making $60 \%$ of these homophones preferable for language research with young and older adults. The mean percentages for homophones labeled as dominant and subordinate in Table A3 are reported at the bottom of Table A3 and were very similar across age groups.

In our attempt to identify the stimuli that young and older adults gave at least one strong, identical association to and rated consistently for dominance, we compared the association responses for only those homophone sets that had an obviously dominant and subordinate homophone. The asterisks next to the homophones in Table A3 indicate the homophones that (1) were rated similarly in dominance by young and older adults, and (2) shared an association given by at least $29 \%$ of young adults and $31 \%$ of older adults. These percent cutoffs correspond to the median association strength for each age group; the median was chosen as a cutoff because of the positive skew in the percentage of free association responses.

Table A4 includes homophones that (1) did not contain a dominant homophone for at least one of the age groups (as identified above in which a homophone had to be rated as dominant by no less than $50 \%$ of the participants), or (2) were inconsistently rated across age group (i.e., young adults rated one homophone in a set as dominant, whereas older adults rated the same homophone as subordinate). As an example, altar/alter are included in Table A4 because older adults were equally likely to rate altar and alter as dominant, and young adults only slightly favored alter. Also, scent was favored as dominant by young adults, whereas cent was favored by older adults. Researchers should be cautious in using the homophones in Table A4 in research that involves age comparisons because these homophones elicited disagreement between the young and older adults. However, some of the homophones that show strong dominance for young adults (e.g., choral/coral) would be useful for research that involves young adults only.

For the homophones in Tables A3 and A4, we conducted correlations between young and older adults' dominance ratings using the mean percentage of time that a homophone was rated as dominant. In addition, correlations were calculated with word frequencies from Kučera and Francis (1967). Frequencies that exceeded three standard deviations from the mean frequency within a table were excluded from the correlations. For the correlations that included the homophones in Table A3, the homophone in was excluded because of its outlying frequency. The correlations that included homophones in Table A4 excluded the homophone one.

The young and older adults' dominance ratings for the homophones in Table A3 were significantly correlated across age groups $[r(119)=.96, p<.001]$. This exceedingly high correlation supports our claim that dominance ratings for these homophones are consistent between young and older adults. Furthermore, Kučera and Francis's (1967) frequencies were correlated with both young adults' $[r(118)=.31, p<.001]$ and older adults' $[r(198)=.32, p<.001]$ dominance ratings. These findings are consistent with and similar to Kreuz's (1987) finding of a correlation between familiarity and frequency.

In contrast to the dominance ratings for the homophones in Table A3, those for the homophones in Table A4 were not significantly correlated across age groups $[r(79)=$ $.11, p>.32]$. Furthermore, there were no significant correlations between frequency and the mean ratings for either young adults $[r(79)=.01, p>.95]$ or older adults $[r(79)=.07, p>.52]$. These findings support our separation of these homophones from those in Table A3: The homophones in Table A4 do not show consistent ratings across age group and do not have a strong dominant member within each set.

We conducted a final set of correlations to test whether participants' free associations were related to their assessment of dominance. No significant correlations were found between the dominance percentages reported in Table A3 and the first association response percentages reported in Tables A1 and A2 for young or older adults, nor for dominant or subordinate homophones. For dominant homophones, the correlation between dominance percentage and first response percentage was .15 for young adults and .04 for older adults $(p \mathrm{~s}>.27)$. For subordinate homophones, the correlations were .00 and -.03 for young and older adults, respectively $(p s>.80)$. Thus, dominance is independent of the association given for the homophone. 


\section{GENERAL DISCUSSION}

The normative data presented here indicate that free association responses and dominance ratings of homophones showed some consistency between young and older adults, indicated by first association agreement for over two-thirds of the homophones and dominance agreement for over half of the homophones. This intermediate consistency generally agrees with other findings for semantic associations, where age differences sometimes emerge and other times do not, depending on variables such as participant vocabulary and word frequency (Burke \& Peters, 1986; Lovelace \& Cooley, 1982; Perlmutter, 1978, 1979; Riegel \& Riegel, 1964; Scialfa \& Margolis, 1986). Prior to our demonstration of both age differences and similarities in the present study, researchers were vulnerable to using homophones that had not been normed across age groups, and only tentative conclusions could be drawn about age-related differences because age effects could be attributed to different associations or dominance representations for the homophones. The data reported here indicate that researchers need to be aware of potential age-related differences that may occur from differences in access to meaning for phonologically ambiguous words. ${ }^{2}$

Researchers interested in using homophones in studies of semantic association should find the results of Tables A1 and A2 helpful, whether the studies only use young adults or compare age groups. The homophones that were responded to with similar associations from young and older adults offer many promising word stimuli for future research. In fact, only two of the 197 homophones did not have at least one overlapping response by young and older adults. The results of the free association survey should also inform research pertaining to the strength of associations to homophones; even within first responses, the response rate ranged from $2.5 \%$ to $92.8 \%$ for young adults and from $5.1 \%$ to $91.3 \%$ for older adults, suggesting that first responses are not always strong associates.

The results of the dominance survey revealed slightly less consistency across age groups, offering 58 homophone sets that were rated similarly by both age groups. These results might explain conflicting age-related results from priming studies that used homophone frequency estimates rather than age-normed dominance estimates (Davis et al., 1990; Howard, 1988; Rose et al., 1986). Future research that includes young and older adult cohorts and utilizes homophone dominance should use homophones reported in Table A3. Furthermore, researchers might use the homophones in Table A4 if studying only one age cohort. However, because of the problems with the homophones listed in Table A4, we do not suggest using these homophone sets if researchers are interested in equating young and older adults on homophone dominance.

Although the data reported here serve to fill a gap in the literature with respect to age-normed homophones, additional normative studies are needed to more precisely specify the independent contributions of frequency and dominance in influencing word retrieval. Given the age differences reported for homophones, age norms are also needed for other ambiguous words (i.e., homonyms and homographs) that are frequently used in lexical research. In addition, the homophone studies reported here could be supplemented with studies that ask participants to free associate to and rate the dominance of auditorypresented homophones. Auditory-presented homophones might lend themselves to a more automatic response of the first word that comes to mind (particularly if response times were recorded), and the results thus obtained would be comparable to previous norms reported for young adults (e.g., Galbraith \& Taschman, 1969), as well as the norms reported here.

In summary, we hope that the norms presented in this article will lead to more carefully controlled studies investigating lexical ambiguity, word retrieval and recognition, and semantic processes with young and older adults. Because homophones share phonology but differ in semantics and orthography, they are unique research tools that can be used to better understand the interaction of these three variables in language production and comprehension. Homophones can also be used to examine age-related differences in access to phonology, orthography, and semantics, research that is still in its infancy (e.g., Taylor \& Burke, 2002; White \& Abrams, 2004).

\section{REFERENCES}

BaAyen, R. H., Piepenbrock, R., \& van Rijn, H. (1993). The CELEX lexical database. Philadelphia: University of Pennsylvania, Linguistic Data Consortium.

Bowles, N. L., \& Poon, L. W. (1982). An analysis of the effect of aging on recognition memory. Journal of Gerontology, 37, 212-219.

Brown, G. D. A. (1984). A frequency count of 190,000 words in the London-Lund Corpus of English Conversation. Behavior Research Methods, Instruments, \& Computers, 16, 502-532.

Burke, D. M., \& Peters, L. (1986). Word associations in old age: Evidence for consistency in semantic encoding during adulthood. Psychology \& Aging, 1, 283-292.

Carroll, J. B., Davies, P., \& Richman, B. (1971). The American Heritage word frequency book. New York: American Heritage.

DAHL, H. (1979). Word frequencies of spoken American English. Essex, CT: Verbatim.

Davis, H. P., Cohen, A., Gandy, M., Colombo, P., VanDusseldorp, G., Simolke, N., \& Romano, J. (1990). Lexical priming deficits as a function of age. Behavioral Neuroscience, 104, 288-297.

Forster, K. L., \& Chambers, S. M. (1973). Lexical access and naming time. Journal of Verbal Learning \& Verbal Behavior, 12, 627-635.

Galbraith, G. G., \& Taschman, C. S. (1969). Homophone units: A normative and methodological investigation of the strength of component elements. Journal of Verbal Learning \& Verbal Behavior, 8, 737-744.

GoRfEIN, D. S., Viviani, J. M., \& LedDo, J. (1982). Norms as a tool for the study of homography. Memory \& Cognition, 10, 503-509.

Gottlob, L. R., Goldinger, S. D., Stone, G. O., \& Van Orden, G. C. (1999). Reading homographs: Orthographic, phonological, and semantic dynamics. Journal of Experimental Psychology: Human Perception \& Performance, 25, 561-574.

HowARD, D. V. (1988). Implicit and explicit assessment of cognitive aging. In M. L. Howe \& C. J. Brainerd (Eds.), Cognitive development in adulthood: Progress in cognitive development research (pp. 3-37). New York: Springer-Verlag.

Kemper, S., \& Sumner, A. (2001). The structure of verbal abilities in young and older adults. Psychology \& Aging, 16, 312-322. 
KreuZ, R. J. (1987). The subjective familiarity of English homophones. Memory \& Cognition, 15, 154-168.

KuČERA, H., \& FranCIS, W. N. (1967). Computational analysis of presentday American English. Providence, RI: Brown University Press.

Lesch, M. F., \& PollatseK, A. (1993). Automatic access of semantic information by phonological codes in visual word recognition. Journal of Experimental Psychology: Learning, Memory, \& Cognition, 19, 285-294.

Lovelace, E. A., \& Cooley, S. (1982). Free associations of older adults to single words and conceptually related word triads. Journal of Gerontology, 37, 432-437.

Lukatela, G., \& Turvey, M. T. (1994). Visual lexical access is initially phonological: I. Evidence from associative priming by words, homophones, and pseudohomophones. Journal of Experimental Psychology: General, 123, 107-128.

Lund, K., \& Burgess, C. (1996). Producing high-dimensional semantic spaces from lexical co-occurrence. Behavior Research Methods, Instruments, \& Computers, 28, 203-208.

MetaMetrics, Inc. (2003). MetaMetrics word frequency counts [Database]. Durham, NC: Author.

Mish, F. C. (ED.) (1991). Webster's ninth new collegiate dictionary. Springfield, MA: Merriam-Webster.

Nelson, D. L., McEvoy, C. L., Walling, J. R., \& Wheeler, J. W., JR. (1980). The University of South Florida homograph norms. Behavior Research Methods \& Instrumentation, 12, 16-37.

Olson, G. A., \& Kausler, D. H. (1971). Orthographic distinctiveness of homonyms. Behavior Research Methods \& Instrumentation, 3, 298-299.

Perlmutter, M. (1978). What is memory aging the aging of? Developmental Psychology, 14, 330-345.

Perlmutter, M. (1979). Age differences in the consistency of adults' associative responses. Experimental Aging Research, 5, 549-553.

RIEGEL, K. F., \& RIEGEL, R. M. (1964). Changes in associative behavior during later years of life: A cross-sectional analysis. Vita $\mathrm{Hu}$ mana, 7, 1-32.

Rose, T. L., Yesavage, J. A., Hill, R. D., \& Bower, G. B. (1986). Priming effects and recognition memory in young and elderly adults. Experimental Aging Research, 12, 31-37.

Scialfa, C. T., \& Margolis, R. B. (1986). Age differences in the commonality of free associations. Experimental Aging Research, 12, 95-98.

Simpson, G. B. (1984). Lexical ambiguity and its role in models of word recognition. Psychological Bulletin, 96, 316-340.

TAYLOR, J. K., \& BURKE, D. M. (2002). Asymmetric aging effects on semantic and phonological processes: Naming in the picture-word interference task. Psychology \& Aging, 17, 662-676.

THORNDIKE, E. L., \& LORGE, I. (1944). The teacher's word book of 30,000 words. New York: Columbia University, Teachers College.

Twilley, L. C., Dixon, P., TAYlor, D., \& ClaRK, K. (1994). University of Alberta norms of relative meaning frequency for 566 homographs. Memory \& Cognition, 22, 111-126.

VAN ORDEN, G. C. (1987). A ROWS is a ROSE: Spelling, sound, and reading. Memory \& Cognition, 15, 181-198.

Verhaeghen, P. (2003). Aging and vocabulary scores: A meta-analysis. Psychology \& Aging, 18, 332-339.
Vu, H., Kellas, G., \& Paul, S. T. (1998). Sources of sentence constraint on lexical ambiguity resolution. Memory \& Cognition, 26, 979-1001.

White, K. K., \& Abrams, L. (2004). Phonological priming of preexisting and new associations in young and older adults. Journal of Experimental Psychology: Learning, Memory, \& Cognition, 30, 645-655.

Zeno, S. M., Ivens, S. H., Millard, R. T., \& Duvvuri, R. (1995). The educator's word frequency guide. Brewster, NY: Touchstone Applied Science.

\section{ARCHIVED MATERIALS}

The following materials associated with this article may be accessed through the Psychonomic Society's Norms, Stimuli, and Data archive, http://www.psychonomic.org/archive/.

To access these files or links, search the archive for this article using the journal (Behavior Research Methods, Instruments, \& Computers), the first author's name (White) and the publication year (2004).

FILE: White-BRMIC-2004.zip

DESCRIPTION: The compressed archive file contains:

whiteabrams2004norms.xls, containing the norms developed by White and Abrams (2004), as a 101K file generated by Microsoft Excel. There are four worksheets in this file, one for each table in the article: Table A1-young adults' free association norms, Table A2-older adults' free association norms, Table A3 - dominance norms with agreement across age group, and Table A4 dominance norms with no consistent agreement across age group. Each row represents one homophone. Columns are labeled as follows. For Tables A1 and A2: Homophone, $N$ (number of participants who gave an association response to that homophone), Response 1 (the response given by the most participants), Response $1 \%$ (the percentage of participants who gave that response). The remaining columns contain the additional responses for each homophone, along with their percentage of response. For Tables A3 and A4, each row contains a homophone, its Kučera and Francis (1967) frequency, and the percentage of young and older adults who rated that homophone as dominant, respectively. The norms provided in whiteabrams2004norms.xls are also available in .csv format, each table represented by a separate document.

AUTHOR's E-MAIL ADDRESS: whitek@cofc.edu.

AutHOR's WeB SITE: http://www.cofc.edu/ whitek/.

\section{NOTES}

1. These homophones were also verified for identical phonology in Webster's Ninth Collegiate Dictionary. However, a small number of homophones (e.g., click, clique) may differ in pronunciation across different dialects.

2. Although these data limit us to a discussion of between-group differences, potential interindividual variability in responses suggests that researchers should try to use the first or second strongest associate when possible because these are the words that are given most often and by the most individuals. Interindividual variability would likely increase with the weaker associates. 
APPENDIX

Table A1

Results of the Free Association Survey for Young Adults, With the Top Two Most Frequently Given Responses

\begin{tabular}{|c|c|c|c|c|c|}
\hline $\begin{array}{c}\text { Homophone } \\
\text { ( } N \text { Responses) }\end{array}$ & $\begin{array}{l}\text { Most Frequent } \\
\text { Response }(\%)\end{array}$ & $\begin{array}{c}\text { Second } \\
\text { Most Frequent } \\
\text { Response }(\%)\end{array}$ & $\begin{array}{c}\text { Homophone } \\
\text { (N Responses) }\end{array}$ & $\begin{array}{l}\text { Most Frequent } \\
\text { Response }(\%)\end{array}$ & $\begin{array}{c}\text { Second } \\
\text { Most Frequent } \\
\text { Response }(\%)\end{array}$ \\
\hline ail (154) & sick (28.6) & pain $(9.7)$ & ferry (213) & boat (71.4) & ride (2.8) \\
\hline ale (202) & beer (47.0) & ginger (11.4) & fir $(175)$ & tree $(54.3)$ & \\
\hline aisle (203) & church (18.2) & $\operatorname{row}(\mathrm{s})(10.4)$ & fur (216) & coat $(35.6)$ & animal (13.5) \\
\hline isle (196) & island (23.4) & & flea $(216)$ & $\operatorname{dog}(22.7)$ & tick (14.8) \\
\hline $\operatorname{altar}(212)$ & $\operatorname{church}(33.1)$ & wedding (9.9) & flee $(211)$ & run (40.9) & leave (8.5) \\
\hline alter (214) & change (36.5) & ego (6.5) & flew (213) & bird (24.4) & (air)plane (18.3) \\
\hline ant (214) & eater (12.6) & bug (10.7) & flu (219) & sick (53.4) & cold $(18.7)$ \\
\hline aunt (212) & uncle (45.3) & relative (3.3) & flue (135) & chimney (10.3) & glue (2.2) \\
\hline ate $(214)$ & food (41.6) & eat (7.9) & gait (152) & walk (29.6) & horse (6.6) \\
\hline eight (209) & nine (36.9) & ball (11.5) & gate (210) & open (20.0) & fence (13.4) \\
\hline bail (201) & jail (46.3) & out (10.4) & genes $(217)$ & DNA (25.8) & genetic(s) (9.7) \\
\hline bale (161) & hay (55.3) & & jeans $(215)$ & blue (42.8) & pants (9.3) \\
\hline beach $(218)$ & sand (45.4) & ocean (6.9) & gorilla (215) & monkey (28.8) & ape (20.0) \\
\hline beech (157) & nut (15.8) & tree $(10.8)$ & guerrilla (205) & war(fare) (51.2) & \\
\hline bell (211) & $\operatorname{ring}(46.5)$ & tower (6.6) & grays (179) & hair (16.7) & color(s) (13.9) \\
\hline belle (186) & beaut(y, iful) (23.0) & southern (10.7) & graze $(208)$ & $\operatorname{cow}(\mathrm{s})(35.1)$ & grass (16.8) \\
\hline berry (212) & blue (20.3) & fruit (13.3) & grisly (200) & meat (2.5) & ugly (2.0) \\
\hline bury (202) & dead, death, die (23.3) & $\operatorname{dig}(7.9)$ & grizzly (219) & bear $(92.8)$ & \\
\hline billed (187) & money $(28.8)$ & duck (9.1) & groan $(210)$ & moan (44.3) & pain (12.9) \\
\hline build (207) & house (33.4) & construct $(13.0)$ & grown (210) & up $(27.6)$ & tall $(9.0)$ \\
\hline bite (217) & teeth $(9.2)$ & me (6.9) & hail (206) & storm (18.9) & rain $(12.1)$ \\
\hline byte (204) & computer $(58.4)$ & mega (7.8) & hale (166) & & \\
\hline blew (212) & wind (17.9) & away (14.6) & hay (211) & horse(s) (41.2) & stack (8.6) \\
\hline blue (218) & sky (23.0) & green (11.9) & hey (211) & you (32.3) & hi (21.3) \\
\hline bold (202) & beautiful (15.9) & daring (7.4) & hear (214) & ear(s) (21.9) & sound(s) (14.9) \\
\hline bowled (170) & ball (17.6) & $\operatorname{pin}(s)(10.6)$ & here (213) & there $(48.4)$ & now (39.4) \\
\hline brews $(210)$ & beer $(66.3)$ & coffee $(7.6)$ & hi $(217)$ & bye (43.3) & hello (19.8) \\
\hline bruise (215) & hurt (14.5) & blue $(9.8)$ & high (213) & low (39.0) & sky (3.8) \\
\hline brows (198) & eye(s) (63.6) & pluck(ed) (6.1) & $\operatorname{him}(215)$ & her (84.3) & \\
\hline browse (211) & look (38.5) & shop (11.0) & hymn (211) & song (38.9), & church (25.5) \\
\hline carat $(208)$ & diamond (47.6) & gold (28.4) & & sing (10.0) & \\
\hline carrot $(215)$ & orange (22.8) & cake $(10.2)$ & hole (211) & ground (12.3) & golf $(8.5)$ \\
\hline cellar (212) & wine (27.9) & basement (20.8) & whole (209) & half (11.5) & thing (8.6) \\
\hline seller (198) & buy(er) (43.4) & book (4.0) & idle (204) & car (16.2) & hand(s) (8.4) \\
\hline cent $(218)$ & penny (31.2) & money (22.1) & idol (201) & Billy (26.4) & worship (10.0) \\
\hline scent $(209)$ & smell (38.3) & perfume (21.5) & in (216) & out (78.3) & side $(2.3)$ \\
\hline sent $(205)$ & mail(ed) (34.1) & letter(s) (10.3) & inn (219) & hotel (44.4) & holiday (8.2) \\
\hline cereal $(215)$ & breakfast (14.5) & milk (12.6) & knight (216) & $\operatorname{armor}(36.1)$ & shining (8.4) \\
\hline serial (216) & killer $(45.5)$ & number (36.6) & night (220) & day (44.6) & dark (15.5) \\
\hline choral (194) & sing(er, ing) (26.8), & choir (6.2) & ladder (210) & $\operatorname{climb}(36.2)$ & $\operatorname{step}(\mathrm{s})(9.5)$ \\
\hline & song (11.3) & & latter (194) & later (19.1) & former $(10.3)$ \\
\hline coral $(217)$ & $\operatorname{reef}(59.0)$ & sea $(6.0)$ & links (207) & chain $(28.0)$ & golf $(10.6)$ \\
\hline clause (196) & Santa $(33.2)^{*}$ & sentence (9.2) & $\operatorname{lynx}(171)$ & cat (38.6) & animal (12.3) \\
\hline claws (212) & $\operatorname{cat}(\mathrm{s})(19.2)$ & bear(s) (17.3) & loan (211) & money (59.8) & bank (10.5) \\
\hline click (201) & mouse (15.4) & clock (13.4) & lone (197) & ranger (21.3) & $\operatorname{star}(13.7)$ \\
\hline clique (188) & group (33.4) & friend(s) $(9.0)$ & mail (219) & letter(s) (19.5) & box (13.0) \\
\hline colonel (196) & army (19.9) & Sanders (13.7) & male (211) & female (73.0) & boy (4.3) \\
\hline kernel (216) & $\operatorname{corn}(51.0)$ & popcorn (34.8) & main (200) & street $(32.0)$ & entrance (7.5) \\
\hline crews (198) & $\operatorname{ship}(\mathrm{s})(21.2)$ & boat(s) (19.7) & mane (210) & horse (66.3) & hair (14.3) \\
\hline cruise (220) & ship (41.9) & boat (18.2) & maize (189) & $\operatorname{corn}(61.3)$ & rice $(2.1)$ \\
\hline days $(218)$ & week(s) (34.9) & night(s) (28.9) & maze (202) & lost (13.9) & mouse (11.4) \\
\hline daze $(210)$ & confuse (d) (42.0) & stare (4.8) & mall (217) & shop(ping) (55.4) & clothes (9.2) \\
\hline dear (209) & letter (16.8) & John (9.6) & maul (167) & hurt (10.8) & bear $(10.8)$ \\
\hline deer $(212)$ & doe (20.3) & animal (11.8) & might (202) & maybe (21.8) & strength, strong (15.3) \\
\hline dense $(208)$ & thick (21.7) & fog $(8.2)$ & mite (192) & bug(s) (22.4) & flea(s) $(5.7)$ \\
\hline dents $(201)$ & $\operatorname{car}(63.7)$ & teeth $(6.0)$ & mind (208) & brain $(29.3)$ & think (9.2) \\
\hline doe $(214)$ & deer $(60.3)$ & John (6.1) & mined (194) & gold (25.8) & coal (23.2) \\
\hline dough (214) & cookie (27.6) & bread (19.2) & naval (211) & ship (10.5) & academy (9.4) \\
\hline dual (205) & two (31.3) & both (3.9) & navel (212) & belly (button) (37.3) & orange (20.3) \\
\hline duel (209) & fight (35.9) & sword(s) (10.6) & nay (194) & no $(25.3)$ & yeah (9.3) \\
\hline earn (212) & money (60.8) & work (5.2) & neigh (177) & horse (60.4) & \\
\hline urn $(200)$ & $\operatorname{ash}(\mathrm{es})(26.0)$ & dead, death (28.0) & none (197) & zero $(15.7)$ & some $(12.7)$ \\
\hline ewe (168) & sheep (23.2) & animal (11.9) & nun (206) & church (19.4) & priest (14.1) \\
\hline you (209) & me $(76.1)$ & $\operatorname{are}(3.8)$ & oh (205) & no $(30.2)$ & my $(22.5)$ \\
\hline fairy (217) & tale $(37.0)$ & godmother (12.6) & owe (210) & money $(60.5)$ & $\operatorname{debt}(8.1)$ \\
\hline
\end{tabular}


APPENDIX (Continued)

\begin{tabular}{|c|c|c|c|c|c|}
\hline \multicolumn{6}{|c|}{ Table A1 (Continued) } \\
\hline $\begin{array}{l}\text { Homophone } \\
\text { (N Responses) }\end{array}$ & $\begin{array}{l}\text { Most Frequent } \\
\text { Response }(\%)\end{array}$ & $\begin{array}{c}\text { Second } \\
\text { Most Frequent } \\
\text { Response }(\%)\end{array}$ & $\begin{array}{l}\text { Homophone } \\
\text { (N Responses) }\end{array}$ & $\begin{array}{l}\text { Most Frequent } \\
\text { Response }(\%)\end{array}$ & $\begin{array}{c}\text { Second } \\
\text { Most Frequent } \\
\text { Response }(\%)\end{array}$ \\
\hline one (212) & two $(53.8)$ & time (4.7) & scene (196) & play (19.4) & movie (17.9) \\
\hline won (212) & $\begin{array}{l}\text { lost }(25.5) \\
\text { lose(r) }(5.2)\end{array}$ & prize $(8.0)$ & $\begin{array}{l}\text { seen }(186) \\
\text { sea }(217)\end{array}$ & $\begin{array}{l}\text { saw }(39.2) \\
\text { ocean }(30.4)\end{array}$ & $\begin{array}{l}\text { heard (6.9) } \\
\text { water }(16.2)\end{array}$ \\
\hline pail (211) & bucket (38.4) & water (18.5) & see $(213)$ & eye(s) (22.5) & look (13.1) \\
\hline pale $(212)$ & white $(34.0)$ & skin $(6.1)$ & seam $(201)$ & sew (19.9) & clothes $(9.5)$ \\
\hline pain (209) & hurt (28.7) & ouch (10.6) & seem $(170)$ & appear (13.6) & like $(9.4)$ \\
\hline pane (202) & window (68.3) & glass (9.9) & sewn (169) & clothes (17.1) & needle (14.2) \\
\hline pair (213) & two $(33.8)$ & shoes (28.6) & sown (146) & $\operatorname{seed}(\mathrm{s})(17.3)$ & oats $(6.8)$ \\
\hline pear $(212)$ & fruit (49.1) & apple (14.6) & sight (212) & see $(22.2)$ & eye(s) (20.2) \\
\hline pare (125) & fruit (12.6) & apple (8.0) & site (198) & place $(14.1)$ & construction (12.1) \\
\hline pause $(207)$ & stop (49.8) & wait (7.7) & sign (207) & stop (34.7) & language (8.7) \\
\hline paws $(216)$ & $\operatorname{dog}(\mathrm{s})(32.2)$ & $\operatorname{cat}(\mathrm{s})(19.9)$ & sine (159) & cosine $(52.8)$ & math (10.7) \\
\hline peak $(210)$ & mountain (44.8) & top $(9.1)$ & stair (218) & case $(17.9)$ & climb (15.6) \\
\hline peek (205) & a boo $(21.0)$ & look (18.0) & stare $(202)$ & look (25.3) & eye(s) (10.4) \\
\hline peer $(211)$ & friend(s) $(26.1)$ & look (14.2) & steal (205) & take $(15.1)$ & thief, theft (13.2) \\
\hline pier (208) & dock (17.8) & fish(ing) (10.1) & steel (208) & metal (25.5) & hard $(8.7)$ \\
\hline plain $(208)$ & Jane (16.8) & simple (8.7) & straight (215) & line $(21.0)$ & narrow (12.1) \\
\hline plane (213) & fly $(28.2)$ & air (19.7) & strait (194) & water (9.8) & jacket (4.6) \\
\hline pride (197) & prejudice $(11.7)$ & joy (11.7) & throne (216) & king (69.0) & queen (6.0) \\
\hline pried (197) & open(ed) $(50.3)$ & pull(ed) (2.5) & thrown (210) & ball (32.9) & away (10.0) \\
\hline quarts $(211)$ & milk (21.3) & gallon(s) (18.1) & thyme (181) & spice(s) (23.8) & herb(s) (17.1) \\
\hline quartz (208) & watch (20.2) & diamond (16.9) & time (206) & clock (33.0) & watch $(10.7)$ \\
\hline $\operatorname{rap}(215)$ & music (34.9) & song (19.1) & toe $(217)$ & foot, feet (45.4) & nail (11.0) \\
\hline wrap (211) & present(s) (15.2) & up (14.2) & tow $(218)$ & $\operatorname{car}(35.8)$ & truck $(33.5)$ \\
\hline real $(208)$ & fake $(25.0)$ & world (10.1) & vain (187) & mirror (9.6) & conceit(ed) (6.8) \\
\hline reel (209) & fish(ing) (49.3) & $\operatorname{rod}(8.6)$ & vane $(163)$ & weather (22.7) & wind (4.9) \\
\hline right $(216)$ & left $(34.7)$ & wrong (33.3) & vein $(208)$ & blood (42.3) & artery (14.4) \\
\hline write (209) & pen $(21.1)$ & down (14.4) & wail (199) & cry $(43.7)$ & scream (6.0) \\
\hline rite $(177)$ & passage (28.8) & aid (9.6) & whale (212) & big (17.9) & ocean $(9.5)$ \\
\hline ring (218) & bell(s) (19.3) & finger (18.3) & waist (206) & $\operatorname{hip}(\mathrm{s})(13.6)$ & belt $(9.7)$ \\
\hline wring (188) & clothes (10.6) & out $(10.6)$ & waste $(210)$ & garbage (22.9) & basket (19.0) \\
\hline $\operatorname{root}(210)$ & tree $(30.5)$ & plant(s) (18.1) & weak (212) & strong $(56.2)$ & tired $(2.8)$ \\
\hline route $(213)$ & road (17.9) & sixty-six (15.5) & week (211) & day(s) (30.4) & month (12.3) \\
\hline rose $(216)$ & flower(s) (27.3) & red $(14.4)$ & yoke (202) & ox(en) (16.4) & joke (2.0) \\
\hline rows $(214)$ & boat(s) (16.9) & columns (15.0) & yolk (213) & $\operatorname{egg}(s)(83.6)$ & \\
\hline
\end{tabular}

Note-Although only two responses are presented here, the reader can find the results of the top four responses in the Archived Materials. *Although "Santa" has traditionally been linked with claus and not clause, we cannot be sure whether participants were thinking about a recent movie titled The Santa Clause when they responded.

Table A2

Results of the Free Association Survey for Older Adults, With the Top Two Most Frequently Given Responses

\begin{tabular}{|c|c|c|c|c|c|}
\hline $\begin{array}{c}\text { Homophone } \\
\text { (N Responses) }\end{array}$ & $\begin{array}{l}\text { Most Frequent } \\
\text { Response }(\%)\end{array}$ & $\begin{array}{c}\text { Second } \\
\text { Most Frequent } \\
\text { Response (\%) }\end{array}$ & $\begin{array}{c}\text { Homophone } \\
\text { (N Responses) }\end{array}$ & $\begin{array}{l}\text { Most Frequent } \\
\text { Response }(\%)\end{array}$ & $\begin{array}{c}\text { Second } \\
\text { Most Frequent } \\
\text { Response }(\%)\end{array}$ \\
\hline ail (208) & sick (53.9) & hurt (13.0) & bite (219) & teeth (17.3) & chew (16.9) \\
\hline ale $(218)$ & beer (71.2) & drink (10.6) & byte (197) & computer (57.9) & mega (5.6) \\
\hline aisle (214) & church (33.6) & walk (14.5) & blew (210) & wind $(27.7)$ & horn (8.6) \\
\hline isle (217) & island (24.0) & Capri (7.9) & blue (218) & sky (18.8) & color (12.9) \\
\hline altar (218) & church (46.0) & wedding (12.4) & bold $(210)$ & brave (15.2) & strong (7.6) \\
\hline alter (219) & change (58.3) & ego (6.4) & bowled (201) & over (29.9) & ball(s) (13.4) \\
\hline ant $(216)$ & insect (19.0) & hill(s) (17.6) & brews $(217)$ & beer(s) (53.5) & coffee $(9.7)$ \\
\hline aunt (218) & uncle (66.6) & relative $(12.8)$ & bruise (220) & hurt (35.5) & black and/or blue (13.2) \\
\hline ate $(215)$ & food (31.2) & dinner, dined (11.7) & brows (212) & eye(s) (57.1) & forehead (7.0) \\
\hline eight (212) & nine (43.9) & number (12.8) & browse (217) & look (33.3) & $\operatorname{read}(8.8)$ \\
\hline bail (213) & jail (26.3) & bond (16.4) & carat $(215)$ & diamond (55.9) & ring (16.8) \\
\hline bale $(217)$ & hay (81.2) & cotton $(4.1)$ & carrot $(218)$ & vegetable (25.9) & orange (12.8) \\
\hline beach $(220)$ & sand (45.9) & ocean $(14.1)$ & cellar $(220)$ & basement (30.9) & wine (12.7) \\
\hline beech (195) & $\operatorname{tree}(\mathrm{s})(60.5)$ & nut (12.3) & seller (215) & buyer $(69.3)$ & salesman (2.8) \\
\hline bell (217) & ring $(53.0)$ & tower $(7.8)$ & cent $(218)$ & penny (40.5) & dollar (17.5) \\
\hline belle (217) & ball (43.4) & girl (11.1) & scent $(219)$ & smell (43.9) & odor (25.3) \\
\hline berry (218) & fruit (27.6) & straw(berry) (19.8) & sent $(213)$ & mail(ed) (32.4) & letter (10.3) \\
\hline bury (215) & $\operatorname{dig}(20.0)$ & dead (19.5) & cereal (216) & breakfast (24.1) & oat(s), oatmeal (17.6) \\
\hline billed (198) & owe(d) (12.1) & pay, paid (10.1) & serial $(215)$ & number(s) (25.1) & killer $(22.8)$ \\
\hline build (216) & house $(30.2)$ & construct $(18.9)$ & & & \\
\hline
\end{tabular}


APPENDIX (Continued)

\begin{tabular}{|c|c|c|c|c|c|}
\hline \multicolumn{6}{|c|}{ Table A2 (Continued) } \\
\hline $\begin{array}{l}\text { Homophone } \\
\text { (N Responses) }\end{array}$ & $\begin{array}{l}\text { Most Frequent } \\
\text { Response }(\%)\end{array}$ & $\begin{array}{c}\text { Second } \\
\text { Most Frequent } \\
\text { Response }(\%)\end{array}$ & $\begin{array}{c}\text { Homophone } \\
\text { (N Responses) }\end{array}$ & $\begin{array}{l}\text { Most Frequent } \\
\text { Response }(\%)\end{array}$ & $\begin{array}{c}\text { Second } \\
\text { Most Frequent } \\
\text { Response (\%) }\end{array}$ \\
\hline choral (217) & $\begin{array}{l}\text { sing }(40.6), \\
\text { song (11.9) }\end{array}$ & group (12.1) & $\begin{array}{l}\text { latter (206) } \\
\text { links (219) }\end{array}$ & $\begin{array}{l}\text { last (26.2) } \\
\text { golf (57.6) }\end{array}$ & $\begin{array}{l}\text { former }(9.7) \\
\text { chain(s) }(11.4)\end{array}$ \\
\hline coral $(220)$ & $\operatorname{reef}(40.4)$ & sea (18.7) & lynx (208) & $\operatorname{cat}(\mathrm{s})(44.7)$ & animal (30.3) \\
\hline clause (203) & sentence (18.7) & phrase (10.8) & loan $(215)$ & money (45.2) & borrow (11.2) \\
\hline claws (219) & $\operatorname{cat}(\mathrm{s})(21.5)$ & bear(s) 10.0 & lone (214) & one $(15.4)$ & ranger (15.0) \\
\hline click (212) & clack (18.4) & clock (16.5) & mail (217) & letter(s) (26.3) & $\operatorname{man}(11.6)$ \\
\hline clique (198) & group (48.0) & $\operatorname{set}(5.6)$ & male (219) & female $(70.8)$ & $\operatorname{man}(15.6)$ \\
\hline colonel (218) & army (33.1) & Sanders (7.8) & main (214) & street $(27.1)$ & stream $(6.5)$ \\
\hline kernel (218) & $\operatorname{corn}(82.1)$ & nut (3.2) & mane (216) & horse (61.2) & hair (16.7) \\
\hline crews (216) & $\operatorname{ship}(s)(18.2)$ & boat(s) (14.7) & maize (214) & $\operatorname{corn}(58.4)$ & yellow (6.5) \\
\hline cruise (220) & $\operatorname{ship}(55.5)$ & boat (14.2) & $\operatorname{maze}(203)$ & puzzle (29.1) & lost (8.4) \\
\hline days $(220)$ & night(s) (49.1) & week(s) (29.6) & mall (217) & shop(s, ing) (54.0) & store(s) (20.3) \\
\hline daze (207) & confused (11.5) & stun(ned) (8.2) & maul (216) & hurt $(21.3)$ & $\operatorname{dog}(\mathrm{s})(7.4)$ \\
\hline dear (219) & love $(12.5)$ & sweet(heart) (7.9) & might $(210)$ & strong (19.5) & maybe (16.2) \\
\hline deer (218) & doe (32.2) & animal (17.0) & mite (214) & small (20.6) & bug (15.5) \\
\hline dense (217) & thick $(50.3)$ & fog(gy) (15.2) & mind (216) & brain (18.5) & matter (15.3) \\
\hline dents (216) & $\operatorname{car}(\mathrm{s})(27.0)$ & fender(s) (14.9) & mined (215) & coal (19.6) & $\operatorname{dug}(16.7)$ \\
\hline doe $(220)$ & deer $(64.5)$ & buck (11.4) & naval (219) & $\operatorname{ship}(s)(19.2)$ & academy (4.1) \\
\hline dough (219) & bread (42.0) & money (12.3) & navel (217) & orange (38.2) & belly $(29.0)$ \\
\hline dual (216) & two $(44.0)$ & double (6.5) & nay $(215)$ & no (41.9) & yea $(9.8)$ \\
\hline duel (218) & fight (52.3) & sword (9.2) & neigh (209) & horse(s) (72.2) & whinny (3.9) \\
\hline earn (219) & money (40.2) & work (20.6) & none (195) & zero $(24.1)$ & some $(21.0)$ \\
\hline urn $(215)$ & vase $(29.3)$ & ashes (18.6) & nun (206) & Catholic (18.5) & priest (15.5) \\
\hline ewe (213) & sheep (35.7) & lamb (30.1) & oh (204) & my (21.6) & $\mathrm{ah}(18.6)$ \\
\hline you (214) & me (78.5) & & owe (209) & debt (26.3) & money (24.4) \\
\hline fairy (217) & tale(s) (40.5) & godmother (15.3) & one (215) & two (59.1) & single (11.2) \\
\hline ferry $(220)$ & boat (76.9) & water $(6.0)$ & won $(215)$ & lost (45.1) & prize $(7.4)$ \\
\hline fir (219) & tree $(81.8)$ & pine (4.2) & pail (206) & bucket (43.7) & water (23.3) \\
\hline fur (219) & coat (39.8) & $\operatorname{animal}(\mathrm{s})(21.5)$ & pale (216) & wan $(13.0)$ & white (10.2) \\
\hline flea (218) & $\operatorname{dog}(25.7)$ & bite $(13.8)$ & pain $(215)$ & $\operatorname{hurt}(\mathrm{s})(34.9)$ & ache (17.2) \\
\hline flee $(217)$ & $\operatorname{run}(57.7)$ & escape (4.6) & pane $(218)$ & window (60.4) & glass (35.4) \\
\hline flew (214) & $\operatorname{bird}(s)(24.3)$ & plane (6.6) & pair (220) & two $(60.9)$ & shoes (8.6) \\
\hline flu (218) & sick (39.4) & cold (18.3) & pear $(217)$ & fruit (44.7) & apple (12.9) \\
\hline flue $(211)$ & chimney (47.9) & fireplace (8.1) & pare $(210)$ & peel (24.8) & cut (15.3) \\
\hline gait (218) & walk (34.1) & horse (24.4) & pause (218) & stop (33.5) & wait (24.9) \\
\hline gate (218) & fence $(24.3)$ & open (22.9) & paws $(218)$ & $\operatorname{dog}(s)(26.2)$ & feet $(22.5)$ \\
\hline genes (192) & DNA (21.3) & heredity (9.9) & peak (219) & top $(25.1)$ & mountain (21.5) \\
\hline jeans (219) & pants (39.7) & blue (27.4) & peek (216) & look (43.8) & a boo (19.1) \\
\hline gorilla (215) & ape (48.0) & monkey (15.8) & peer (214) & equal (25.3) & look (20.6) \\
\hline guerrilla (215) & war(fare) (27.9) & fighter (10.7) & pier (218) & dock (31.3) & boat (13.8) \\
\hline grays (202) & color(s) (15.3) & blue(s) (10.9) & plain (215) & simple $(20.5)$ & fancy (16.3) \\
\hline graze (217) & eat $(27.2)$ & $\operatorname{cow}(\mathrm{s})(15.7)$ & plane (219) & fly $(33.8)$ & air (17.9) \\
\hline grisly (216) & ugly (5.1) & gore(y) (3.9) & pride (207) & prejudice (22.3) & fall (9.2) \\
\hline grizzly (219) & bear $(91.3)$ & & pried (212) & open $(40.0)$ & loose (7.6) \\
\hline groan (219) & moan $(45.2)$ & hurt (8.7) & quarts $(218)$ & $\operatorname{pint}(\mathrm{s})(43.8)$ & milk (21.1) \\
\hline grown (217) & up $(25.8)$ & adult (18.5) & quartz (216) & stone $(26.4)$ & watch (14.8) \\
\hline hail (219) & ice $(10.1)$ & storm (9.6) & $\operatorname{rap}(214)$ & knock (23.4) & $\operatorname{tap}(14.5)$ \\
\hline hale (203) & hearty (57.7) & healthy (4.9) & wrap (215) & present (9.3) & package (9.3) \\
\hline hay (218) & bale (13.3) & straw (12.8) & real $(216)$ & true $(16.2)$ & fake (8.8) \\
\hline hey (213) & hello (19.7) & hi (15.5) & reel $(215)$ & fish(ing) (48.3) & $\operatorname{rod}(27.0)$ \\
\hline hear (211) & listen (19.0) & ear(s) (18.4) & right (219) & wrong (50.3) & left (36.5) \\
\hline here (217) & there $(65.9)$ & now (20.3) & write (216) & letter (20.8) & read (14.8) \\
\hline hi (216) & hello (28.8) & bye (11.2) & rite (201) & ceremony (18.9) & passage (16.4) \\
\hline high $(220)$ & low $(65.5)$ & up (4.5) & ring (219) & finger (26.1) & bell(s) (19.2) \\
\hline him (218) & her (78.9) & he (3.2) & wring (214) & clothes (16.3) & twist (14.5) \\
\hline hymn (219) & song (44.7), & church (18.4) & $\operatorname{root}(217)$ & tree $(26.8)$ & plant(s) (15.6) \\
\hline & sing (16.9) & & route (219) & $\operatorname{road}(22.9)$ & way (17.9) \\
\hline hole (215) & dig, dug (17.7) & ground (8.8) & rose (219) & flower (39.9) & garden (7.3) \\
\hline whole (214) & all (19.7) & half (15.4) & rows $(211)$ & boat (15.7) & corn $(15.7)$ \\
\hline idle (203) & lazy (25.1) & busy (12.8) & scene (208) & picture (19.7) & play (11.6) \\
\hline idol (211) & worship (16.5) & $\operatorname{god}(10.5)$ & seen $(208)$ & saw (27.4) & look (8.7) \\
\hline in (219) & out $(84.1)$ & & sea $(220)$ & ocean $(35.0)$ & water (14.5) \\
\hline inn (219) & hotel (42.9) & motel (13.7) & see (212) & look (23.6) & saw (15.1) \\
\hline knight (216) & armor (45.9) & king (8.4) & seam (214) & sew (42.6) & dress (9.3) \\
\hline night $(220)$ & day (71.8) & dark (13.6) & seem (188) & appear(s) (25.0) & like (11.7) \\
\hline ladder (217) & climb (40.1) & $\operatorname{step}(s)(17.1)$ & sewn (201) & clothes $(6.0)$ & torn $(6.0)$ \\
\hline
\end{tabular}


APPENDIX (Continued)

\begin{tabular}{|c|c|c|c|c|c|}
\hline \multicolumn{6}{|c|}{ Table A2 (Continued) } \\
\hline $\begin{array}{l}\text { Homophone } \\
\text { ( } N \text { Responses) }\end{array}$ & $\begin{array}{l}\text { Most Frequent } \\
\text { Response (\%) }\end{array}$ & $\begin{array}{c}\text { Second } \\
\text { Most Frequent } \\
\text { Response }(\%)\end{array}$ & $\begin{array}{c}\text { Homophone } \\
\text { (N Responses) }\end{array}$ & $\begin{array}{l}\text { Most Frequent } \\
\text { Response (\%) }\end{array}$ & $\begin{array}{c}\text { Second } \\
\text { Most Frequent } \\
\text { Response (\%) }\end{array}$ \\
\hline sown (216) & $\operatorname{seed}(\mathrm{s})(37.1)$ & plant(ed) (14.0) & time (212) & clock (18.9) & day (10.3) \\
\hline sight (216) & $\operatorname{see}(n)(28.7)$ & eye(s) (17.3) & toe $(218)$ & foot, feet (58.7) & nail (17.0) \\
\hline site $(214)$ & place $(35.1)$ & location (10.3) & tow (219) & pull $(33.8)$ & $\operatorname{car}(15.5)$ \\
\hline $\operatorname{sign}(214)$ & post (7.3) & name $(6.2)$ & vain (185) & proud, pride (14.1) & conceited (4.9) \\
\hline sine $(155)$ & cosine $(27.7)$ & math (16.7) & vane $(207)$ & weather $(66.7)$ & wind(s) (5.3) \\
\hline stair (218) & step (s) (21.6) & climb (17.9) & vein (219) & blood (45.4) & artery (24.3) \\
\hline stare (214) & look $(50.1)$ & eye(s) (8.9) & wail (215) & $\operatorname{cry}(68.3)$ & moan (3.3) \\
\hline steal (214) & take (21.6) & $\operatorname{rob}(19.1)$ & whale (217) & fish (18.0) & big (13.5) \\
\hline steel (214) & iron $(25.7)$ & metal (11.2) & waist (214) & belt (15.0) & line $(11.7)$ \\
\hline straight (219) & crooked (23.7) & narrow (21.9) & waste (213) & garbage (12.7) & $\operatorname{trash}(12.7)$ \\
\hline strait (215) & water(way) (23.0) & jacket (9.8) & weak (217) & strong (63.6) & sick (5.1) \\
\hline throne (216) & king (57.0) & chair $(9.7)$ & week (218) & day(s) (34.9) & seven $(20.7)$ \\
\hline thrown (218) & $\operatorname{toss}(\mathrm{ed})(21.1)$ & ball (19.8) & yoke (219) & ox(en) $(32.5)$ & horse (6.4) \\
\hline thyme (203) & spice(s) (25.1) & herb(s) (24.6) & yolk (219) & $\operatorname{egg}(86.7)$ & white(s) (3.2) \\
\hline
\end{tabular}

Note-Although only two responses are presented here, the reader can find the results of the top four responses in the Archived Materials.

Table A3

Mean Percentage of Times a Homophone Was Chosen as Dominant in the Dominance Survey, With Consistent Ratings Across Age Group

\begin{tabular}{|c|c|c|c|c|c|c|c|}
\hline Homophone ${ }^{\mathrm{a}}$ & KF-FREQ & Young Adults ${ }^{b}$ & Older Adults ${ }^{b}$ & Homophone $^{\mathrm{a}}$ & KF-FREQ & Young Adults ${ }^{b}$ & Older Adults $^{\mathrm{b}}$ \\
\hline ail* & 0 & 10.5 & 26.4 & fir* & 2 & 3.6 & 9.1 \\
\hline ale* & 1 & 70.3 & 51.8 & fur* & 13 & 89.5 & 63.2 \\
\hline aisle & 6 & 59.5 & 75.5 & gait* & 8 & 2.2 & 6.4 \\
\hline isle & 5 & 19.5 & 12.7 & gate & 37 & 92.7 & 80.9 \\
\hline ant & 6 & 19.1 & 16.4 & gorilla & 0 & 79.5 & 54.1 \\
\hline aunt* & 22 & 55.9 & 55.0 & guerrilla & 1 & 8.6 & 26.1 \\
\hline bail & 7 & 73.6 & 57.3 & grisly & 2 & 7.8 & 13.6 \\
\hline bale* & 5 & 11.4 & 23.6 & grizzly* & 1 & 74.0 & 58.6 \\
\hline beach* & 61 & 96.4 & 97.3 & groan* & 1 & 27.7 & 13.2 \\
\hline beech* & 6 & 1.4 & 0.0 & grown & 43 & 53.2 & 70.9 \\
\hline bell* & 18 & 94.5 & 90.0 & hail & 10 & 69.7 & 65.5 \\
\hline belle & 1 & 2.3 & 4.1 & hale & 2 & 10.1 & 12.3 \\
\hline billed & 3 & 13.6 & 14.1 & hay & 15 & 5.5 & 35.0 \\
\hline build & 86 & 66.8 & 61.8 & hey & 19 & 86.4 & 50.0 \\
\hline bite & 10 & 72.7 & 66.4 & him* & 2,619 & 92.3 & 84.5 \\
\hline byte* & 0 & 14.5 & 21.8 & hymn* & 9 & 7.3 & 8.6 \\
\hline blew & 12 & 5.9 & 7.8 & idle & 13 & 50.2 & 68.6 \\
\hline blue & 143 & 68.9 & 64.4 & idol & 7 & 28.8 & 14.1 \\
\hline bold & 21 & 86.8 & 80.0 & in* & 21,341 & 76.3 & 73.6 \\
\hline bowled & $23^{c}$ & 7.3 & 8.6 & inn* & 9 & 12.8 & 12.3 \\
\hline brews* & $4^{c}$ & 7.3 & 17.4 & knight* & 18 & 8.6 & 4.1 \\
\hline bruise & 3 & 84.5 & 68.9 & night* & 411 & 82.7 & 91.8 \\
\hline brows* & $6^{c}$ & 10.5 & 16.4 & ladder* & 19 & 78.1 & 67.1 \\
\hline browse* & 0 & 80.0 & 67.7 & latter & 114 & 10.0 & 16.4 \\
\hline carat* & 0 & 6.8 & 6.4 & links & 7 & 86.8 & 89.5 \\
\hline carrot & 1 & 77.6 & 87.3 & lynx* & 0 & 5.9 & 1.4 \\
\hline karat & 0 & 0.0 & 0.0 & loan* & 46 & 75.5 & 58.6 \\
\hline cereal & 17 & 67.6 & 67.3 & lone & 8 & 10.0 & 18.2 \\
\hline serial & 7 & 12.3 & 9.5 & main & 119 & 90.9 & 91.8 \\
\hline cite & 7 & 1.8 & 3.6 & mane* & 0 & 4.5 & 4.5 \\
\hline sight & 86 & 73.5 & 70.9 & maize* & 0 & 7.3 & 16.4 \\
\hline site & 64 & 11.9 & 10.0 & maze & 6 & 87.3 & 59.1 \\
\hline click & 2 & 66.4 & 75.8 & mall* & 3 & 91.3 & 95.0 \\
\hline clique* & 2 & 16.8 & 14.6 & maul & 0 & 3.2 & 2.3 \\
\hline crews & $36^{c}$ & 5.9 & 14.1 & might & 672 & 95.5 & 96.3 \\
\hline cruise* & 2 & 85.5 & 67.3 & mite & 1 & 3.2 & 1.8 \\
\hline days & $686^{c}$ & 85.4 & 93.6 & mind & 325 & 93.6 & 95.9 \\
\hline daze & 0 & 5.9 & 1.4 & mined & $59^{c}$ & 3.2 & 0.5 \\
\hline dear & 54 & 56.4 & 70.5 & none & 108 & 82.2 & 90.5 \\
\hline deer & 13 & 18.6 & 10.5 & nun & 2 & 8.2 & 5.0 \\
\hline earn* & 16 & 93.2 & 96.4 & pain* & 88 & 89.5 & 81.4 \\
\hline urn & 2 & 5.5 & 1.4 & pane* & 3 & 3.7 & 4.5 \\
\hline ewe & 1 & 0.9 & 1.8 & pair* & 50 & 57.5 & 61.2 \\
\hline you* & 3,286 & 95.9 & 94.1 & pare* & 2 & 0.5 & 0.0 \\
\hline
\end{tabular}


APPENDIX (Continued)

Table A3 (Continued)

\begin{tabular}{|c|c|c|c|c|c|c|c|}
\hline Homophone ${ }^{a}$ & KF-FREQ & Young Adults ${ }^{b}$ & Older Adultsb & Homophone $^{\mathrm{a}}$ & KF-FREQ & Young Adults $^{\mathrm{b}}$ & Older Adults $^{b}$ \\
\hline pear & 6 & 25.6 & 17.4 & steal & 5 & 64.1 & 51.8 \\
\hline pause* & 21 & 69.1 & 63.6 & steel & 45 & 13.2 & 17.3 \\
\hline paws* & $3^{c}$ & 14.5 & 18.2 & straight & 114 & 90.9 & 91.4 \\
\hline pride & 42 & 95.4 & 87.2 & strait & 5 & 3.2 & 2.7 \\
\hline pried* & $6^{c}$ & 0.9 & 5.0 & throne* & 5 & 19.2 & 13.6 \\
\hline real & 260 & 91.3 & 91.8 & thrown & 40 & 68.5 & 74.1 \\
\hline reel* & 2 & 4.6 & 2.7 & thyme & 0 & 2.3 & 7.3 \\
\hline ring & 47 & 90.9 & 84.1 & time & 1,599 & 93.6 & 84.5 \\
\hline wring & 2 & 0.9 & 3.6 & toe* & 9 & 57.5 & 66.8 \\
\hline rose & 86 & 68.6 & 55.0 & tow & 1 & 16.9 & 12.3 \\
\hline rows & $35^{\mathrm{c}}$ & 20.9 & 24.1 & vain & 10 & 20.5 & 15.5 \\
\hline seam & 9 & 6.4 & 10.0 & vane & 0 & 3.2 & 1.8 \\
\hline seem & 229 & 82.7 & 76.4 & vein* & 25 & 55.7 & 60.5 \\
\hline sign & 94 & 94.1 & 99.5 & whale* & 0 & 77.2 & 70.5 \\
\hline sine & 4 & 4.5 & 0.0 & wail & 3 & 10.0 & 9.1 \\
\hline sewn & 1 & 55.5 & 54.1 & Dominant $M(S D)$ & & $78.3(13.4)$ & $74.8(14.5)$ \\
\hline sown & 3 & 14.2 & 13.2 & Subordinate $M(S D)$ & & $9.4(6.9)$ & $10.5(7.7)$ \\
\hline
\end{tabular}

*Indicates those homophones that, for young and older adults, were similarly rated for dominance and had strong and matching first response associations. aDominant homophones within a set are indicated by bold font. bThe responses do not always add to $100 \%$ because participants were allowed to rate the homophones as equal in dominance. 'Some homophones that are the plural or past tense of another word were not included in Kučera and Francis (1967), and therefore the frequencies are reported here for those homophones' singular or present tense.

Table A4

Mean Percentage of Time a Homophone Was Chosen as Dominant, With No Consistency Across Age Group

\begin{tabular}{|c|c|c|c|c|c|c|c|}
\hline Homophone & KF-FREQ & Young Adults ${ }^{\mathrm{a}}$ & Older Adults $^{\mathrm{a}}$ & Homophone & KF-FREQ & Young Adults ${ }^{\mathrm{a}}$ & Older Adults $^{\mathrm{a}}$ \\
\hline altar & 5 & 32.4 & 36.8 & hi & 6 & 58.7 & 29.7 \\
\hline alter & 15 & 40.2 & 35.5 & high & 497 & 15.6 & 48.4 \\
\hline ate & 16 & 42.9 & 51.8 & hole & 58 & 14.2 & 13.6 \\
\hline eight & 104 & 21.0 & 11.8 & whole & 309 & 50.7 & 48.6 \\
\hline berry & 6 & 45.0 & 42.7 & mail & 47 & 29.1 & 28.6 \\
\hline bury & 9 & 29.5 & 29.1 & male & 37 & 36.8 & 27.7 \\
\hline cellar & 26 & 38.4 & 13.2 & naval & 33 & 43.2 & 43.6 \\
\hline seller & 6 & 47.0 & 70.5 & navel & 2 & 38.6 & 34.5 \\
\hline cent & 158 & 21.9 & 33.9 & nay & 2 & 32.9 & 37.4 \\
\hline scent & 6 & 35.6 & 23.4 & neigh & 0 & 29.2 & 21.5 \\
\hline sent & 145 & 16.0 & 9.6 & oh & 119 & 54.6 & 27.7 \\
\hline choral & 2 & 12.3 & 46.4 & owe & 10 & 28.4 & 44.5 \\
\hline coral & 5 & 68.6 & 34.1 & one & 3,292 & 41.8 & 51.8 \\
\hline clause & 9 & 25.6 & 41.8 & won & 68 & 24.1 & 16.8 \\
\hline claws & $1^{\mathrm{b}}$ & 54.5 & 42.3 & pail & 4 & 20.5 & 28.6 \\
\hline colonel & 37 & 25.0 & 35.9 & pale & 58 & 55.3 & 41.8 \\
\hline kernel & 3 & 50.9 & 48.2 & peak & 16 & 40.9 & 36.1 \\
\hline dense & 9 & 65.9 & 46.4 & peek & 0 & 32.7 & 33.8 \\
\hline dents & $2^{b}$ & 19.1 & 29.1 & plain & 48 & 27.1 & 30.5 \\
\hline doe & 1 & 9.1 & 75.0 & plane & 114 & 41.3 & 36.8 \\
\hline dough & 13 & 71.4 & 12.7 & peer & 8 & 65.3 & 40.5 \\
\hline dual & 9 & 56.6 & 8.6 & pier & 3 & 19.6 & 40.5 \\
\hline duel & 5 & 23.7 & 73.2 & quarts & $3^{b}$ & 44.7 & 78.2 \\
\hline fairy & 4 & 56.9 & 34.1 & quartz & 1 & 29.2 & 10.9 \\
\hline ferry & 11 & 17.9 & 39.5 & rap & 2 & 45.9 & 12.7 \\
\hline flea & 2 & 50.7 & 37.3 & wrap & 5 & 36.4 & 75.9 \\
\hline flee & 1 & 28.3 & 37.3 & right & 613 & 56.4 & 35.2 \\
\hline flew & 27 & 38.4 & 42.7 & rite & 8 & 0.0 & 0.0 \\
\hline flu & 8 & 48.9 & 43.6 & write & 106 & 28.2 & 48.4 \\
\hline flue & 0 & 0.5 & 0.5 & root & 30 & 35.2 & 19.5 \\
\hline genes & $9^{b}$ & 10.0 & 63.6 & route & 43 & 41.6 & 57.7 \\
\hline jeans & 1 & 67.1 & 14.1 & scene & 106 & 32.9 & 17.7 \\
\hline grays & $80^{\mathrm{b}}$ & 32.9 & 33.6 & seen & 279 & 42.9 & 58.6 \\
\hline graze & 1 & 45.7 & 41.4 & sea & 95 & 15.0 & 12.7 \\
\hline hear & 153 & 28.2 & 20.1 & see & 772 & 46.8 & 59.5 \\
\hline here & 750 & 28.2 & 29.7 & stair & 2 & 44.5 & 48.2 \\
\hline
\end{tabular}


WHITE AND ABRAMS

APPENDIX (Continued)

Table A4 (Continued)

\begin{tabular}{|c|c|c|c|c|c|c|c|}
\hline Homophone & KF-FREQ & Young Adults ${ }^{\mathrm{a}}$ & Older Adults $^{\mathrm{a}}$ & Homophone & KF-FREQ & Young Adults ${ }^{\mathrm{a}}$ & Older Adults $^{\mathrm{a}}$ \\
\hline stare & 14 & 24.1 & 20.5 & week & 275 & 49.8 & 50.9 \\
\hline waste & 35 & 43.6 & 50.0 & yoke & 3 & 12.8 & 81.8 \\
\hline waist & 11 & 25.9 & 15.5 & yolk & 1 & 74.9 & 6.4 \\
\hline weak & 32 & 16.4 & 8.2 & & & & \\
\hline
\end{tabular}

aThe written responses do not always add to $100 \%$ because participants were allowed to rate the homophones as equal in dominance. bSome homophones that are the plural or past tense of another word were not included in Kučera and Francis (1967), and therefore the frequencies are reported here for those homophones' singular or present tense.

(Manuscript received January 1, 2004;

revision accepted for publication July 18, 2004.) 